Images $\ln .$.

\title{
Direct invasion of the left atrium by a primary lung tumour
}

\author{
Marc Dweck, Indrani Bhattacharya, ${ }^{1}$ Olusegun Oduyoye, ${ }^{1}$ Mark Jones, ${ }^{2}$ C Mark Francis'
}

${ }^{1}$ Department of Cardiology, Victoria Hospital, Fife, UK

${ }^{2}$ NHS Fife, Fife, UK

Correspondence to Indrani Bhattacharya, indranisb@doctors.org.uk

\section{DESCRIPTION}

A 47-year-old woman presented with a 1-week history of breathlessness. Clinical examination revealed normal heart sounds, an elevated jugular venous pressure and pitting oedema to the knees. A right-sided transudative pleural effusion was confirmed on chest x-ray (figure 1) and cardiac failure was suspected.

Echocardiography demonstrated normal systolic function, a large mass in the left atrium (LA) and severe pulmonary hypertension (figure 2). The mass appeared to arise from the inter-atrial septum, was smooth surfaced and contained echo-free spaces suggestive of necrotic regions. While it was not clearly pedunculated, a working diagnosis of an atrial myxoma was made and further imaging arranged.

However, overnight our patient deteriorated abruptly becoming hypoxic and hypotensive. A CT scan was arranged, which revealed a hilar lung tumour directly invading the LA and occupying almost its entire area (figure $3 \mathrm{~A}, \mathrm{~B})$. It was felt that intermittent obstruction of the valve by the mass had been responsible for her deterioration. Biopsies at bronchoscopy established a diagnosis of nonsmall cell lung carcinoma. Unfortunately our patient became increasingly unwell and died shortly after.

Although the commonest LA tumour is a myxoma, other tumours especially a lung malignancy should be ruled out. ${ }^{1}$ Otherwise these patients could be referred for cardiac surgery (myxoma excision) and a major lung pathology missed. Chest $\mathrm{x}$-ray was unhelpful in this case because the mass was obscured by the pleural effusion. CT made the diagnosis, which raises the question should all LA tumours be investigated with CT scans?

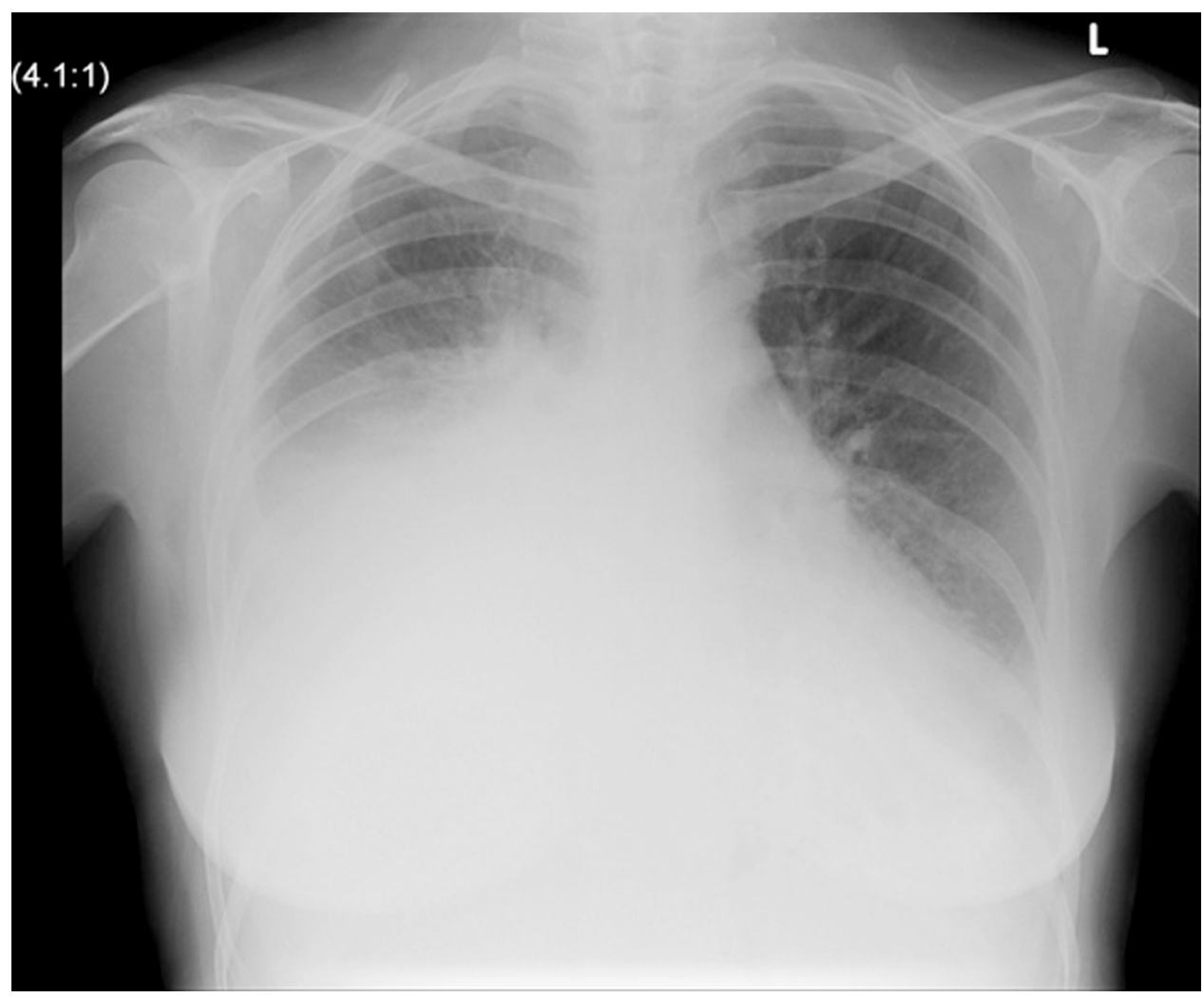

Figure 1 Chest radiograph showing a right-sided pleural effusion. 


\section{BMJ Case Reports}

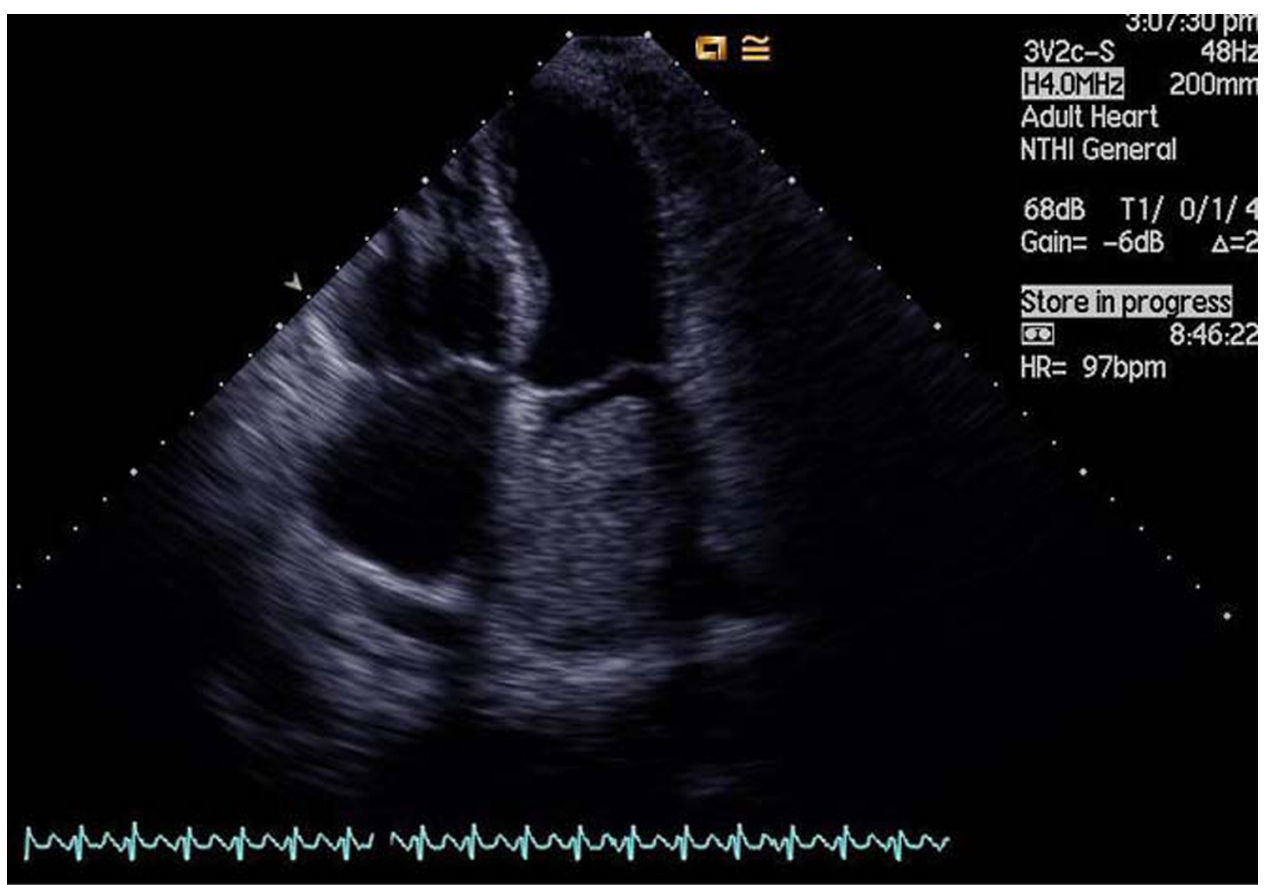

Figure 2 Echocardiogram, apical four-chamber view showing a large mass within the left atrium.
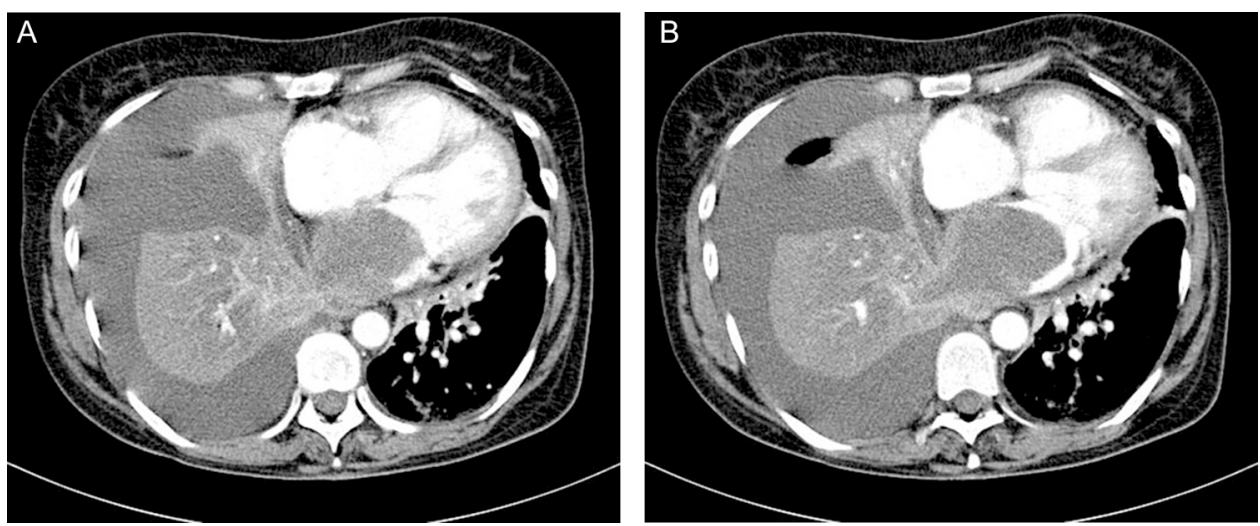

Figure 3 (A, B) CT showing a lung mass in the right hilar region (arrows) infiltrating into the heart and occupying almost the entire left atrium.

\section{REFERENCES}

Competing interests None

Patient consent Obtained.

1. Kodama K, Doi O, Tatsuta M. Unusual extension of lung cancer into the left atrium via the pulmonary vein. Int Surg 1990;75:22-6. 


\section{BMJ Case Reports}

This pdf has been created automatically from the final edited text and images.

Copyright 2010 BMJ Publishing Group. All rights reserved. For permission to reuse any of this content visit http://group.bmj.com/group/rights-licensing/permissions.

BMJ Case Report Fellows may re-use this article for personal use and teaching without any further permission.

Please cite this article as follows (you will need to access the article online to obtain the date of publication).

Dweck M, Bhattacharya I, Oduyoye 0, Jones M, Francis CM. Direct invasion of the left atrium by a primary lung tumour. BMJ Case Reports 2010; 10.1136/bcr.03.2010.2799, date of publication

Become a Fellow of BMJ Case Reports today and you can:

- Submit as many cases as you like

- Enjoy fast sympathetic peer review and rapid publication of accepted articles

Access all the published articles

- Re-use any of the published material for personal use and teaching without further permission

For information on Institutional Fellowships contact consortiasales@bmjgroup.com

Visit casereports.bmj.com for more articles like this and to become a Fellow 